\title{
Effect of Gypsum and Etepon on Crop Yield Siamese Orange (Citrus Nobilis Var. Microcarpa L.)
}

\author{
Tyagita Varenia Anak Agung Istri*, Ni Putu Anom Sulistiawati and Ni Komang Alit Astiari \\ Agrotechnology Study Program, Faculty of Agriculture, Warmadewa University, Indonesia \\ *Corresponding author. E-mail: tyagitavarenia@gmail.com
}

\begin{abstract}
This study aims to determine the effect of Gypsum and Ethephon on the production of Siamese orange (Citrus nobilis Var Microcarpa. L) conducted in Belancan Village, Kintamani District, Bangli Regency from December 2020 to July 2021. This study used a Randomized Block Design with 2 factors arranged in a factorial manner. The first factor that was tried was the dose of gypsum fertilizer $(G)$ which consisted of 4 levels, G0 $(0$ g/tree), G1 (250 g/tree), G2 (500 g/tree), and G3 (750 g/tree). While the second factor is the concentration of ethephon $(E)$ which consists of 3 levels, EO $(0 \mathrm{ml} / \mathrm{l}), E 1(0.75 \mathrm{ml} / \mathrm{l})$ and $E 2(1.5 \mathrm{ml} / \mathrm{l})$. Thus, there were 12 treatment combinations, each of which was repeated 3 times, so 36 citrus trees were needed. The results showed that the interaction of gypsum dose with ethephonconcentration had no significant effect on all observed variables. The highest harvested fruit weight per tree was obtained at a dose of gypsum $750 \mathrm{~g} /$ tree which was $6.32 \mathrm{~kg}$ or an increase of $70.35 \%$ when compared to treatment without gypsum which was only $3.71 \mathrm{~kg}$. The highest harvested fruit weight per tree was obtained inthe ethephon treatment with a concentration of 1.5 $\mathrm{ml} / \mathrm{l} / \mathrm{tree}$, which was $6.54 \mathrm{~kg}$, an increase of $51.38 \%$ compared to the treatment without ethephon.
\end{abstract}

Keywords: dose, etepon, gypsum, Siamese orange, yield

\section{Introduction}

Siamese orange is a commodity after the most popular fruit in the world, grapes. Based on the average production, there are five centers of citrus production in Indonesia, namely, Bali is one of them. The districts that are centers of citrus production in Bali are Gianyar and Bangli Regencies, especially Kintamani District. Siam Kintamani citrus plant is one of the horticultural crops which is a leading commodity in Bali [1]. Based on data sources Central Bureau of Statistics (2020) [3] that citrus production in Bangli Regency reached 101,338 tons in (2017), 102,051 tons in (2018) and 168,476 tons in (2019). National citrus production in 2016 of 2,014,206 has not been able to meet the needs of oranges in Indonesia, this is evidenced by the volume of imports of citrus fruits which reached 2,594,825 tons Central Bureau of Statistics (2016) [2]. With the high volume of imports, Indonesia needs to increase its fresh citrus production again Karina Saphira (2017) [17]. Full fill the needs of Siamese oranges is still difficult, this is due to seasonal harvests, where between September and October the vegetative phase of citrus plants is still developing which causes uneven production. At harvest time or often referred to as the season (on the season) the plants produce abundant harvested fruit, but the low quality of the fruit with small size causes the selling price to below, so a lot of fruit is wasted [5].

The processing of Siamese orange plantations are still being carried out according to farmers habits so that the quality and quantity of Siamese orange produced is not able to compete with imported citrus fruit, it needs to be done improvements in the Siamese citrus cultivation system which refers to the cultivation good and right (Good Agriculture Practices) to get citrus production with good quality. 
Therefore, arrangements are needed so that at harvest time the fruit quality remains excellent and the amount of production is not excessive, while outside the harvest season the plants can produce fruit outside the season with good fruit quality. The low quality of harvested fruit is causedby farmers not following good agricultural practices (GAP) and allowing their plants to bear fruit, GAP is not being considered, especially in unbalanced fertilization, without protected pruning of leaves and twigs as well as diseases and inappropriate harvest time [6]. According to Sumarno (2019)

[25] the reasons for the need for GAP are: 1) improvements to the weaknesses of Green Revolution technology 2) preventing air and land contamination by pesticides, 3) environmental pollution, 4) to control greenhouse gases (GHG) from farming systems, 5) it is necessary GAP in international trade, 6) growing consumer awareness of safe products for consumption, 7) public awareness of quality, production certificates, and eco products, 8) the need for basic worker rights, safety, and agriculture, and 9) the need for a modern goods production system, such as ISO, GMP, GIP, and so on. According to Srivastava et, al (2009) [7] and Garhwal et al (2014) [8] stated that citrus plants can produce well when fertilized with organic fertilizers and fertilizers containing nutrients Nitrogen, Phosphorus, potassium and $\mathrm{Ca}$ with the right dose and time of application. Calcium $(\mathrm{Ca})$ fertilizer has the function of strengthening plants, increasing fruit shelf life, reducing flower fall, fruit and fruit cracking [9]. Functions of Magnesium (Mg): helps the process of photosynthesis, supports plant permeability, increases resistance to pests and diseases, forms nutrients in plants, prevents the loss of flowers and ovules. While Sulfur functions to help the formation of green leaf grains, plays an important role in the process of making sugar, increases the protein and vitamin content of plants. Elemental Ca be obtained in the form of gypsum and dolomite.

Gypsum is a lime compound containing $4.2 \%$ water content, $37.6 \% \mathrm{Ca}, 49.9 \%$ sulfate, and $8.3 \% \mathrm{Mg}$ with the chemical formula $\mathrm{CaSO}_{4} \cdot 2 \mathrm{H}_{2} \mathrm{O}$ [10]. The results of the study Purbiati et, al (2014) [11] showed that the addition of $\mathrm{Ca}$ fertilizer in the form of dolomite could increase the size of citrus fruits and also tend to increase the diameter of citrus fruits. The results of the study Astiari et, al (2020) [5] showed that the application of calcium fertilizer in the form of dolomite at a dose of $500 \mathrm{~g} /$ tree gave the highest weight of fruit harvested per tree, weight per fruit, and several fruits pertree, which was $151.90 \mathrm{~g}$ respectively; $40.0 \mathrm{~kg}$ and 279.42 fruit compared without calcium fertilizer treatment, namely $108.33 \mathrm{~g} ; 22.14 \mathrm{~kg}$, and 200.75 pieces. While the results of the study Sulistiawati (2019) [12] found that the application of $\mathrm{Ca}$ fertilizer in the form of gypsum at a dose of $700 \mathrm{~g} /$ tree gave the highest fruit weight per tree, namely $28.58 \mathrm{~kg}$, an increase of $66.36 \%$ when compared to no gypsum application, which was $17.18 \mathrm{~kg}$.

Currently, there are five main groups of PGR, namely auxins (auxins), cytokinins (cytokinins), gibberellins (gibberellins, GAs), ethylene (ethene, ETH), and abscisic acid (abscisic acid, ABA) [19]. This study uses ZPT ethylene. Ethylene is one of the growth regulators that can cause several plant responses such as epinasty, leaf fall, stem swelling, fruit ripening, flower color changes, and sexual expression. Ethylene currently traded is ethrel 40 PGR with the active ingredient ethephon or 2 chloroethyl phosphonate $\left(\mathrm{CL}-\mathrm{CH}_{2}-\mathrm{CH}_{2}-\mathrm{PO}_{3} \mathrm{H}_{2}\right)$ which in water decomposes into ethylene, $\mathrm{Cl}$ - and $\mathrm{H}_{2} \mathrm{PO}_{4}^{-1}$ [13]. The ability of Ethephon to break dormancy occurs because the release of ethylene will increase the permeability of the cell membrane, thus facilitating the movement of molecules to the cytoplasm which acts as an accelerator of breaking dormancy in buds and flower formation [13]. The results of the study Novita et al (2018) [20] Ethylene given in the form of ethephon can increase the number of female flowers on cucumber plants. The recommended concentration for ethephon is 0.5 $1.0 \mathrm{ml} \mathrm{l}^{-1}$ of water per tree. The results of the study Darmayasa (2017) [13] found that in the ethephon treatment, the highest number of fruit formed per tree in the ethephon treatment was $0.75 \mathrm{ml} \mathrm{l}^{-1}$ water per tree (E1), which was 183.58 fruit, an increase of $12.74 \%$ when compared the treatment without ethephon (E0) which is only 162.83 pieces. 


\section{Material and Methods}

This research was conducted in a citrus orchard in Belancan Village, Kintamani District, Bangli Regency. The altitude of the place is between 1000 - 1200 meters above sea level, with a gentle to hilly topography, a slope of $20-40 \%$, temperatures between $15-30^{\circ} \mathrm{C}$. The air temperature is cool and the rainfall is quite high 2,500 - 3,500 mm Belancan Village Profile (2014)[21], starting from December 2020 to July 2021. This study used a Randomized Block Design (RBD) with 2 factors arranged in a factorial manner. The first factor to be tested was gypsum as fertilizer which consisted of 4 dose levels, namely: G0 control), G1 (250 g/tree), G2 (500 g/tree) and G3 (750 g/tree). While the second factor tested was Ethephon which consisted of 3 concentration levels, namely: E0(control), E1 $(0.75 \mathrm{ml} / \mathrm{l} / \mathrm{tree})$ and E2 $(1.5 \mathrm{ml} / \mathrm{l} / \mathrm{tree})$. Thus, 12 combination treatments were obtained, each of which was repeated 3 times so that 36 Siamese citrus trees were needed. The citrus plants used in this study were 4 years old with a spacing of $3 \times 3 \mathrm{~m}$, with healthy plant conditions, and hadbeen in production. As basic fertilizer, chicken manure was used at a dose of $2 \mathrm{~kg} /$ tree and Nitrogen, Phosphorus, potassium fertilizer at a dose of $250 \mathrm{~g} /$ tree for each plant sample evenly. Gypsum treatment, which was applied once during the study by spreading evenly on the soil at a distance of $50 \mathrm{~cm}$ from the base of the stem with doses according to the levels given, namely 250,500, and 750 $\mathrm{g} /$ tree as treatment. While the Ethephon treatment was given in stages 3 times during the study, namely the first giving a week after the giving of gypsum, the second and third giving each with an interval of one week after the first giving of Ethephon. Giving by spraying on secondary and tertiary branches and leaves of Siamese citrus plants using a hand sprayer with a concentration according to the level of treatment dissolved in 1 liter of water.

The variables observed in this study were: the number of flowers formed per tree (bud), the percentage of flowers that became young fruit (fruit-set) (\%), the number of fruits formed per tree (fruit). Percentage of young fruits that fell per tree (\%), Content Relative water of leaves (\%), number of fruit harvested per tree (fruit), weight per fruit $(\mathrm{g})$, the weight of fruit harvested per tree $(\mathrm{kg})$, and diameter of fruit harvested $(\mathrm{cm})$.

Observational data were tabulated, then statistically analyzed using analysis of variance in accordance with the design used. First, the diversity test is carried out so that the variance is obtained. If the treatment has a significant effect, then the analysis is continued to find a single effect of each factor with the BNT test at $5 \%$ and $1 \%$ levels.

\section{Results and Discussion}

Based on the results of statistical analysis, the significance of the effect of gypsum dose (G) and ethephon concentration (E) and their interaction $(\mathrm{GxE})$ on all observed variables are presented in Table 1. The average of observed variables due to the influence of gypsum fertilizer dose (G) and ethephon concentration (E) are presented in Table 2 and Table 3. While the correlation between variables due to the effect of gypsum and ethephon doses is presented in Table 4 and Table 5. 
Table 1.

Significance of Gypsum (G) and Etepon (E) doses and their interactions (GxE) on all observed variables

\begin{tabular}{|c|c|c|c|c|}
\hline No. & Variable & $\begin{array}{c}\text { Gypsum } \\
\text { Dosage } \\
(\mathrm{G})\end{array}$ & $\begin{array}{l}\text { Perlakuan } \\
\text { Concentration } \\
\text { Ethephon } \\
\text { (E) }\end{array}$ & $\begin{array}{c}\text { Interaction } \\
(\mathrm{GxE})\end{array}$ \\
\hline 1 & Number of flowers formed per tree (bud) & $* *$ & $* *$ & ns \\
\hline 2 & Percentage of flowers to fruit (fruit-set) $(\%)$ & $* *$ & $* *$ & ns \\
\hline 3 & Number of fruit formed per tree (fruit) & $* *$ & $* *$ & ns \\
\hline 4 & Relative water content of leaves (\%) & $* *$ & $* *$ & ns \\
\hline 5 & Number of harvested fruit per tree (fruit) & $* *$ & $* *$ & ns \\
\hline 6 & Percentage of young fruit fall per tree $(\%)$ & $*$ & $* *$ & ns \\
\hline 7 & Fruit diameter $(\mathrm{cm})$ & $*$ & $* *$ & ns \\
\hline 8 & Weight per fruit $(\mathrm{g})$ & $*$ & $*$ & ns \\
\hline 9 & Weight of harvested fruit per tree $(\mathrm{kg})$ & $*$ & $*$ & $\mathrm{~ns}$ \\
\hline \multicolumn{2}{|c|}{ Note: } & & & \\
\hline
\end{tabular}

From Table 1 it can be explained that the interaction between the gypsum dose and the concentration of ethephon (GxE) had no significant effect on all observed variables. The gypsum $(\mathrm{G})$ dose treatment had a significant to a very significant effect on all observed variables. While ethephon (E) had a significant effect on weight per fruit and weight of harvested fruit per tree and had a very significant effect on other variables. Gypsum treatment with a dose of $750 \mathrm{~g} /$ tree (G3) gave the highest harvested fruit weight per tree which was $6.32 \mathrm{~kg}$ or an increase of $70.35 \%$ when compared to treatment without gypsum (G0) which was only $3.71 \mathrm{~kg}$ (Table 2). Magnesium also plays a role in regulating the formation of sugars and starches from the breakdown of carbohydrate compounds, and increases the total dissolved solids which also plays a role in the increase in fruit weight [23]. The increase in harvested fruit weight per tree at a dose of $750 \mathrm{~g} /$ tree (G3) was supported by fruit diameter $\left(\mathrm{r}=0.994^{* *}\right)$; weight per fruit $\left(\mathrm{r}=0.983^{* *}\right)$, and the number of fruits harvested per tree $\left(\mathrm{r}=0.851^{*}\right)$ (Table 4).

The highest fruit diameter, weight per fruit, and a number of harvested fruit were obtained at a dose of $750 \mathrm{~g} /$ tree $(\mathrm{G} 3)$, which were $7.54 \mathrm{~cm} ; 112.11 \mathrm{~g}$ and 47.44 pieces were compared to the treatment without gypsum (G0) which was only $5.37 \mathrm{~cm} ; 104.11 \mathrm{~g}$ and 26.00 pieces (Table 2). The increase in the number of fruit harvested at a dose of $750 \mathrm{~g} /$ tree (G3) was also supported by an increase in the number of flowers per tree $\left(\mathrm{r}=0.902^{* *}\right)$ and the number of fruits formed per tree $(\mathrm{r}$ $=0.983 * *$ ) (Table 4.). Gypsum is a lime compound containing $4.2 \%$ water content, $37.6 \% \mathrm{Ca}, 49.9 \%$ sulfate and $8.3 \% \mathrm{Mg}$ [10]. According to Srivastava, AK (2009) [7] calcium (Ca) can function to stimulate the formation and increase flower growth, is very appropriate to prevent flower and fruit loss, helps translocation and distribution of starch and phosphorus in plants that play a role in fruit formation and fruit weight, can stimulate root growth, improve plant health so that it is not susceptible to disease. According to Mukhlis (2017) [22] elements of Ca plays a role in cell growth. Ca component that strengthens, and regulates penetration, and maintains cell walls. Its role is very important at the point of root growth. Ca plays a role in the process of cell division and elongation, and regulates the distribution of photosynthetic products. While magnesium $(\mathrm{Mg})$ functions in the process of forming chlorophyll, also supports the formation of nutrients in plants (sugars, carbohydrates, fats, proteins, and oils); can prevent the fall of flowers and fruit. While Sulfur functions to help the formation of green leaf grains so that the leaves become greener, plays an important role in the photosynthesis process, especially the manufacture of sugars, increasing the protein and vitamin content of the harvest. 
Thus, from the three functions of the above elements, especially $\mathrm{Ca}, \mathrm{Mg}$ and $\mathrm{S}$ contained in gypsum, it can increase the photosynthetic process so that more photosynthesis is produced and can stimulate the formation of more flowers and can prevent flower fall. Rahma et al (2015) [15] stated that with increased protein synthesis and increased sink strength of flower buds compared to vegetative shoots, more assimilate translocation to flower buds was followed by higher flower formation and followed by higher flower development into fruit. This can be proven in this study by increasing the number of flowers formed per tree, the highest was obtained in the gypsum treatment at a dose of $750 \mathrm{~g} /$ tree (G3), namely 76.11 buds, an increase of $40.66 \%$ when compared to the lowest value obtained in the treatment without gypsum (G0) which is only 54.11 buds. The increase in the number of flowers per tree at the gypsum treatment dose of $750 \mathrm{~g} /$ tree (G3) can cause the number of fruit formed per tree to be higher $\left(\mathrm{r}=0.917^{* *}\right)$ (Table 4), which is 49.67 fruit, an increase of $57.38 \%$ compared to gypsum treatment (G0) which is only 31.56 pieces (Table 3). The increase in the number of fruits formed per tree, besides being influenced by the increase in the number of flowers per tree, was also influenced by the percentage of fruit-set $\left(\mathrm{r}=0.983^{* *}\right)$ (Table 4$)$. The highest fruit-set percentage of $51.56 \%$ was obtained in the treatment at a dose of $750 \mathrm{~g} /$ tree (G3) compared to the treatment without gypsum (G0), which was only $29.56 \%$ (Table 3). This shows that gypsum has a rapid effect on the development of flowers into fruit, thereby increasing the percentage of fruit-set. The higher percentage of fruit-set in the gypsum treatment at a dose of $750 \mathrm{~g} /$ tree (G3) compared to the treatment without gypsum $(\mathrm{G} 0)$ could increase the number of harvested fruits per tree $(\mathrm{r}=$ $0.951^{* *}$ ) (Table 4). The increase in the number of harvested fruit per tree, in addition to being supported by an increase in fruit-set, was also associated with a higher relative water content of leaves. The relative water content of the leaves in the gypsum treatment at a dose of $750 \mathrm{~g} /$ tree (G3) was the highest at $89.13 \%$ compared to the treatment without gypsum fertilizer (G0), which was only $77.93 \%$. This shows that the application of gypsum can increase the water status in plant tissues as indicated by an increase in the leaf which causes the metabolic process of plants to increase which causes a higher photosynthesis process as evidenced by the lower percentage of young fruit fall per tree, namely $1.76 \%$. at a dose of gypsum 750 , g/tree (G3) compared to the treatment without gypsum (G0) which reached $9.72 \%$ (Table 2).

Table 2.

The average value of the relative water content of the leaves, number of harvested fruit per tree, weight per fruit, weight of harvested fruit per tree and fruit diameter due to the influence of gypsum dose concentration and ethephon concentration

$\begin{array}{cccccc} & \text { Relative } & \text { Number } & \text { Weight per } & \text { Weight of } & \text { Fruit } \\ \text { water } & \text { of } & \text { fruit } & \text { harvested } & \text { diameter } \\ \text { Treatment } & \text { content of } & \text { harvested } & (\mathrm{g}) & \text { fruit per } & (\mathrm{cm}) \\ & \text { leaves } & \text { fruit per } & & \text { tree } & \\ & (\%) & \text { tree } & & (\mathrm{kg}) & \\ & \text { (fruit) } & & \end{array}$

\begin{tabular}{lcccccc}
\hline GYpsum (G) & $77,93 \mathrm{c}$ & $26,00 \mathrm{~d}$ & $104,11 \mathrm{c}$ & $3,71 \mathrm{~b}$ & $5.37 \mathrm{c}$ \\
$\mathrm{G}_{0}(0 \mathrm{~g} /$ tree $)$ & $85,11 \mathrm{~b}$ & $33,11 \mathrm{c}$ & $105,21 \mathrm{c}$ & $4,58 \mathrm{~b}$ & $6,85 \mathrm{~b}$ \\
$\mathrm{G}_{1}(250 \mathrm{~g} /$ tree $)$ & $86,651 \mathrm{ab}$ & $40,67 \mathrm{~b}$ & $108,17 \mathrm{~b}$ & $5,40 \mathrm{ab}$ & $7,43 \mathrm{a}$ \\
$\mathrm{G}_{2}(500 \mathrm{~g} /$ tree $)$ & $89,13 \mathrm{a}$ & $47,44 \mathrm{a}$ & $112,11 \mathrm{a}$ & $6,32 \mathrm{a}$ & $7,54 \mathrm{a}$ \\
$\mathrm{G}_{3}(750 \mathrm{~g} /$ tree $)$ & $\mathbf{3 , 1 0}$ & $\mathbf{4 , 4 0}$ & $\mathbf{2 , 2 9}$ & $\mathbf{1 . 4 9}$ & $\mathbf{0 , 2 8}$ \\
BNT 0,05 & & & & & & \\
Etepon $(\mathbf{E})$ & $81,15 \mathrm{~b}$ & $34,00 \mathrm{~b}$ & $99,39 \mathrm{c}$ & $4,38 \mathrm{~b}$ & $6,57 \mathrm{~b}$ \\
$\mathrm{E}_{0}(0 \mathrm{ml} / \mathrm{l} /$ tree $)$ & $83,78 \mathrm{~b}$ & $36,08 \mathrm{ab}$ & $110,95 \mathrm{~b}$ & $5,03 \mathrm{ab}$ & $6,76 \mathrm{~b}$ \\
$\mathrm{E}_{1}(0,75 \mathrm{ml} / \mathrm{l} /$ tree $)$ & $89,18 \mathrm{a}$ & $40,33 \mathrm{a}$ & $115,11 \mathrm{a}$ & $6,54 \mathrm{a}$ & $7,06 \mathrm{a}$ \\
$\mathrm{E}_{2}(1,5 \mathrm{ml} / \mathrm{l} /$ tree $)$ & $\mathbf{3 , 8 9}$ & $\mathbf{5 , 0 9}$ & $\mathbf{2 , 6 5}$ & $\mathbf{1 , 5 8}$ & $\mathbf{0 , 3 3}$ \\
BNT 0,05 & & &
\end{tabular}

Note: The average value followed by the same letter in the same treatment and column, means that it is not 
Table 3.

The average value of the variable number of flowers formed per tree, the percentage of flowers becoming young fruit, the number of fruit formed per tree and the percentage of young fruit falling per tree due to the influence of gypsum and ethephon

\begin{tabular}{ccccc}
\hline & $\begin{array}{c}\text { Number of } \\
\text { flowers formed } \\
\text { Treatment }\end{array}$ & $\begin{array}{c}\text { Percentage of } \\
\text { flowers to fruit } \\
\text { per tree }\end{array}$ & $\begin{array}{c}\text { Number of } \\
\text { fruit-set })\end{array}$ & $\begin{array}{c}\text { Percentage of } \\
\text { fruit formed } \\
\text { young fruit fall }\end{array}$ \\
& (bud) & $(\%)$ & (fruit) & per tree
\end{tabular}

\begin{tabular}{lcccc}
\hline Gypsum (G) & $54,11 \mathrm{~d}$ & $29,56 \mathrm{~d}$ & $31,56 \mathrm{~d}$ & $9,72 \mathrm{a}$ \\
$\mathrm{G}_{0}(0 \mathrm{~g} /$ tree $)$ & $62,44 \mathrm{c}$ & $37,67 \mathrm{c}$ & $36,33 \mathrm{c}$ & $5.84 \mathrm{~b}$ \\
$\mathrm{G}_{1}(150 \mathrm{~g} /$ tree $)$ & $72,67 \mathrm{~b}$ & $43,89 \mathrm{~b}$ & $43,89 \mathrm{~b}$ & $2,99 \mathrm{c}$ \\
$\mathrm{G}_{2}(300 /$ tree $)$ & $76,11 \mathrm{a}$ & $51,56 \mathrm{a}$ & $49,67 \mathrm{a}$ & $1,76 \mathrm{c}$ \\
$\mathrm{G}_{3}(450 \mathrm{~g} /$ tree $)$ & $\mathbf{2 , 2 6}$ & $\mathbf{4 , 9 0}$ & $\mathbf{4 , 1 2}$ & $\mathbf{1 , 6 9}$ \\
BNT 0,05 & & & & \\
Ethephon $(\mathbf{E})$ & $64,17 \mathrm{~b}$ & $37,75 \mathrm{~b}$ & $38,33 \mathrm{~b}$ & $6.23 \mathrm{a}$ \\
$\mathrm{E}_{0}(0 \mathrm{ml} / \mathrm{l} /$ tree $)$ & $66,50 \mathrm{ab}$ & $40,33 \mathrm{ab}$ & $40,00 \mathrm{ab}$ & $4,85 \mathrm{ab}$ \\
$\mathrm{E}_{1}(40 \mathrm{ml} / \mathrm{l} /$ tree $)$ & $68,33 \mathrm{a}$ & $43,92 \mathrm{a}$ & $42,75 \mathrm{a}$ & $4,14 \mathrm{~b}$ \\
$\mathrm{E}_{2}(80 \mathrm{ml} / \mathrm{l} /$ tree $)$ & $\mathbf{2 , 7 2}$ & $\mathbf{5 , 6 6}$ & $\mathbf{4 , 2 2}$ & $\mathbf{1 , 9 5}$ \\
BNT 0,05 & &
\end{tabular}

Note: The average value followed by the same letter in the same treatment and column, means that it is not significantly different at the $5 \%$ BNT test level.

In the ethephon concentration treatment $(\mathrm{E})$, the highest harvested fruit weight per tree was obtained in the ethephon treatment with a concentration of $1.5 \mathrm{ml} / \mathrm{l} / \mathrm{tree}$ (E2), which was $6.54 \mathrm{~kg}$, an increase of $49.32 \%$ compared to the treatment without ethephon (E0). ) which is only $4.38 \mathrm{~kg}$ (Table 2). The increase in the weight of harvested fruit per tree in the $1.5 \mathrm{ml} / \mathrm{l}$ (E2) treatment was also supported by an increase in the number of harvested fruits per tree $(\mathrm{r}=0.991 * *)$, weight per fruit $(\mathrm{r}=$ $0.998 * *)$, and fruit diameter. $(\mathrm{r}=0.984 * *)$ (Table 5). The number of harvested fruit per tree, weight per fruit, and the highest fruit diameter were obtained in the ethephon treatment with a concentration of $1.5 \mathrm{ml} / \mathrm{l} /$ tree (E2), which were 40.33 pieces, $115.11 \mathrm{~g}$, and $7.06 \mathrm{~cm}$ respectively, increased by $18.62 \% ; 15.81 \%$ and $7.46 \%$ compared to the treatment without ethephon (E0), which were only 34.00 pieces; $99.39 \mathrm{~g}$ and $6.57 \mathrm{~cm}$ (Table 2). The increase in the number offruits harvested per tree was supported by an increase in the number of flowers $(r=0.997)$ and the number of fruits formed per tree $\left(r=1,000^{* *}\right)$. The number of flowers per tree and the number of fruit formed per tree was highest in the treatment with a concentration of $1.5 \mathrm{ml} / 1 /$ tree (E2), ie 68.33 buds and 42.75 pieces, compared to the treatment without ethephon (E0), which was only 64.17 buds and 38.33 pieces. According to Abidin (1985) in Sinaga (2012) [24], this hormone will playa role in the fruit ripening process in the climacteric phase. The advantages of growth regulators play a role in supporting the flowering process and supporting fruit ripening. The increase in the number of fruits formed per tree is influenced by the increase in the number of flowers per tree, but also by the percentage of fruit set $\left(\mathrm{r}=0.978^{* *}\right)($ Table 5).

The highest fruit-set percentage of $43.92 \%$ was obtained in the treatment with a concentration of $1.5 \mathrm{ml} / \mathrm{l} / \mathrm{tree}$ (E2) compared to that without treatment with ethephon (E0), which was only $37.75 \%$ (Table 3). This shows that the treatment with ethephon concentration has a rapid effect on the development of flowers into fruit, thereby increasing the percentage of fruit-set. The higher percentage of fruit-set in the treatment with a concentration of $1.5 \mathrm{ml} / 1 /$ tree (E2) compared to the treatment without ethephon (E0) could support a higher number of harvested fruits per tree $(\mathrm{r}=$ $0.983^{* *}$ ) and also be associated with higher leaf relative water content of leaves values (Table 2). The relative water content of leaves in the treatment of ethephon $1.5 \mathrm{ml} / \mathrm{l} / \mathrm{tree}$ (E2), which was $89.18 \%$, was significantly higher than the relative water content of leaves value of the leaves in the treatment without ethephon (E0) with a value of $81.15 \%$. This shows that the administration of ethephon can improve the water status of plant tissues as indicated by the increase in leaf Relative water content of leaves. Increased water status of plants can be caused by increasing the ability of 
plants to absorb water or reducing transpiration [16]. This condition causes the metabolic process of plants to increase, as evidenced by the lower percentage of young fruit falling per tree, namely $6.23 \%$ at a concentration of $1.5 \mathrm{ml} / \mathrm{l} / \mathrm{tree}$ (E2) when compared to the treatment without ethephon, which reached $4.14 \% . \%$. The low percentage of young fruit fall per tree in the ethephon treatment with a concentration of $1.5 \mathrm{ml} / \mathrm{l} /$ tree because it is caused by a better photosynthesis process, more photosynthate is produced so that it will support an increase in the number of harvested fruit as well as an increase in weight per fruit and larger fruit diameter. the height which is a supporting component of increasing harvested fruit weight per tree.

Table 4.

The value of the correlation coefficient between variables (r) due to the influence of gypsum dose $(\mathrm{G})$

\begin{tabular}{|c|c|c|c|c|c|c|c|c|c|}
\hline & 1 & 2 & 3 & 4 & 5 & 6 & 7 & 8 & 9 \\
\hline 1 & 1 & & & & & & & & \\
\hline 2 & $0.948 * *$ & 1 & & & & & & & \\
\hline 3 & $0.917 * *$ & $0.983 * *$ & 1 & & & & & & \\
\hline 4 & $0.954 * *$ & $0.979 * *$ & $0.992 * *$ & 1 & & & & & \\
\hline 5 & $-0.978 * *$ & $-0.993 * *$ & $-0.967 * *$ & $-0.977 * *$ & 1 & & & & \\
\hline 6 & $0.986^{* *}$ & $0.951 * *$ & $0.896^{*}$ & $0.924 * *$ & $-0.979 * *$ & 1 & & & \\
\hline 7 & $0.864 *$ & $0.937 * *$ & $0.985^{* *}$ & $0.975 * *$ & $-0.913^{* *}$ & $0.818^{*}$ & 1 & & \\
\hline 8 & $0.943^{* *}$ & $0.987 * *$ & $0.997 * *$ & $0.998 * *$ & $-0.978 * *$ & $0.920 * *$ & $0.977 * *$ & 1 & \\
\hline 9 & $0.902 * *$ & $0.941 * *$ & $0.983 * *$ & $0.987 * *$ & $-0.930 * *$ & $0.851 *$ & $0.994 * *$ & $0.983 * *$ & 1 \\
\hline
\end{tabular}

Table 5.

The value of the correlation coefficient between variables (r) due to the influence of etephon concentration (E)

\begin{tabular}{|c|c|c|c|c|c|c|c|c|c|}
\hline & 1 & 2 & 3 & 4 & 5 & 6 & 7 & 8 & 9 \\
\hline 1 & 1 & & & & & & & & \\
\hline 2 & $0.965^{* *}$ & 1 & & & & & & & \\
\hline 3 & $0.998 *$ & $0.978 * *$ & 1 & & & & & & \\
\hline 4 & $0.995 * *$ & $0.987 * *$ & $0.999 * *$ & 1 & & & & & \\
\hline 5 & $-0.928 * *$ & $-0.993 * *$ & $-0.948 * *$ & $-0.962 * *$ & 1 & & & & \\
\hline 6 & $0.997 * *$ & $0.983 * *$ & $1.000 * *$ & $1.000 * *$ & $-0.955^{* *}$ & 1 & & & \\
\hline 7 & $0.993 * *$ & 0.990 ** & $0.998 * *$ & $1.000^{* *}$ & $-0.966 * *$ & $0.999 * *$ & 1 & & \\
\hline 8 & $1.000 * *$ & $0.965^{* *}$ & $0.999 * *$ & $0.995^{* *}$ & $-0.929 * *$ & $0.997 * *$ & $0.993 * *$ & 1 & \\
\hline 9 & $0.998 * *$ & $0.949 * *$ & $0.994 * *$ & $0.987 * *$ & $-0.906^{* *}$ & $0.991 * *$ & $0.984 * *$ & $0.998 * *$ & 1 \\
\hline
\end{tabular}

notes :

1. Number of flowers formed per tree (bud)

6. Number of harvested fruit per tree (fruit)

2. Percentage of flowers to fruit (fruit-set) $(\%)$

7. Fruit diameter $(\mathrm{cm})$

3. Number of fruit formed per tree (fruit)

8. Weight per fruit $(\mathrm{g})$

4. Relative water content of leaves (\%)

9. Weight of harvested fruit per tree $(\mathrm{kg})$

5. Percentage of young fruit fall per tree $(\%)$

Notes $\quad: \mathrm{ns}=$ Influence is not significant $(\mathrm{P}>0,05)$

* = Have a significant impact $(\mathrm{P}<0,05)$

$* *=$ Very significant impact $(\mathrm{P}<0,01)$ 


\section{Conclusion}

Based on the results of the study, it can be said that the interaction between gypsum dose and concentration had no significant effect on all observed variables. The gypsum treatment had a significant to a very significant effect on all observed variables. The highest harvested fruit weight per tree was obtained at a dose of gypsum $750 \mathrm{~g} /$ tree which was $6.32 \mathrm{~kg}$ or an increase of $70.35 \%$ when compared to treatment without gypsum which was only $3.71 \mathrm{~kg}$. Meanwhile, in the treatment, the concentration of ethephon had a significant to a very significant effect on all observed variables. The highest harvested fruit weight per tree was obtained in the ethephon treatment with a concentration of $1.5 \mathrm{ml} / \mathrm{l} / \mathrm{tree}$, which was $6.54 \mathrm{~kg}$, an increase of $51.38 \%$ compared to the treatment without ethephon which was only $4.32 \mathrm{~kg}$.

\section{References}

[1] Suryana, Achmad. (2005). Kebijakan Ketahanan Pangan Nasional. Makalah FAPERTA, IPB, Bogor, 22 November 2005.

[2] Badan Pusat Statistik. (2016). Produksi buah-buahan menurut provinsi. http//bps.go.id. Accessed 24 December 2020.

[3] Badan Pusat Statistik, 2020. Data Produksi Jeruk Kabupaten Bali. http://bali.bps.go.id/tabel_detail.php?ed=607004\&od=7\&id=7. Accessed 4 December 2020

[4] Stuckens, J., Dzikiti, S., Verstraeten, W.W., Verreynne, S., Swennen, R., Coppin P. (2011). Physiological interpretation of a hyperspectral time series in citrus orchard. Agricultural and Forest Meteorology. 151:10021015.

[5] Astiari, A.N. K., Sulistiawati N. P.A., Rai IN. (2020). Efforts to Produce Siamese Orange Fruit All Year through Application of Flower-Inducing Substance and Calcium Fertilizer. International Journal of Research in Engineering and Science (IJRES)

[6] Astiari, A.N.K., Kartini, L., Sulistiawati, N. P.A., Rai, I.N. (2018). Efforts To Produce Siamese Citrus Fruit Out Of Season And Fruit Quality Improvement Through Application Of Potassium Nitrate And Agrodyke Fertilizer

[7] Srivastava, A.K. (2009). Integrated Nutrient Management : conscept and Apllication in Citrus. Tree and Forest science and Biotechnology. Natural research center for citrus. Maharashtra, India. 27P. Accessed 17 January 2021.

[8] Garhwal, P.C., Yadav, P.K., Sharma, B.D., Singh, R.S., Ramniw, A.S. (2014). Effect of Organic Manure and Nitrogen on Growth Yield and Quality of Citrus in Sandy Soil of Hot Arid Region. African J. of Agric. Res. 9(34):2638-2647.

[9] Khayat, H.M.E., Rehiem, M.A.A. (2013). Improving Mandarin Productivity and Quality by Using Mineral and Bio-Fertilization. Alex. J. Agric. Res. 58(2):141-147.

[10] Sutopo. (2009). Rekomendasi Pemupukan untuk Tanaman Jeruk. Balai Penelitian Tanaman Jeruk dan Buah Subtropika. Badan Penelitian dan Pengembangan Pertanian.

[11] Purbiati, T., Sugiyarto, M., Susanto, D.A. (2014). Pengkajian Penjarangan Buah pada Tanaman Jeruk Siam (Citrus suhuiensi Tan.). Badan Penelitian dan Pengembangan Pertanian, http://balitjestro.litbang.pertanian.go.id/rekomendasi-penjarangan-untuk-tanaman-jeruk/. Accessed 20 November 2019.

[12] Sulistiawati, N.P.A. (2019). Fisiologi Pembungaan dan Produksi Buah Jeruk Siam (Citrus nobillis var microcarpa L.). Disertasi Fakultas Pertanian Universitar Udayana. 2019. 12 Hal.

[13] Darmayasa, W. (2017). Pemberiaan Paklobutrazol dan Etephon terhadap Pembungaan dan Pembuahan Tanaman Jeruk Siam. Skripsi. Program Studi Agroteknologi Fakultas Pertanian Universitas Warmadewa.

[14] Darmawan, M. (2014). Induksi pembungaan diluar musim pada tanaman jeruk keprok (Citrus reticulata). [tesis]. Bogor (ID): Institut Pertanian Bogor.

[15] Rahma, D. E., Yohanes, C. G. dan Azlina, H. (2015). Pengaruh Pemberian Boron terhadap Pertumbuhan dan Produksi dua Varietas Melon (Cucumis melo L.) pada Sistem Hidroponik Media Padat. J. Agrotek Tropika, ISSN 2337 -4993. Vol. 3, No. 1 : 92-98, January 2021.

[16] Rai, I.N., Wiraatmaja, I. W., Semarajaya, C.G.A., Astiari, N.K.A. (2014). Application of Drip Irrigation Technology for Producing Fruit of Salak 'Gula Pasir' (Salacca zalacca var. Gula Pasir) off-Season on Dry Land. Journal of Degraded and Mining Lands Management 2(1): 219-222

[17] Karina, S. (2017). Kepentingan Indonesia Melakukan Impor Buah Jeruk Dari Tiongkok. Accessed January 2021 
Effect of Gypsum and Etepon on Crop Yield Siamese Orange (Citrus Nobilis Var. Microcarpa L.)

[18] Riastana, I.K., Astiari, N.K.A., Sulistiawati, N.PA. (2019). Kualitas Buah Jeruk Siam (Citrus nobillis var microcarva L) Selama Penyimpanan Pada Berbagai Tingkat Kematangan Buah. Program Studi Agroteknologi, Fakultas Pertanian, Universitas Warmadewa

[19] Tyas, S. (2020). http://cybex.pertanian.go.id/artikel/93434/mengenal-berbagai-macam-zat-pengatur-tumbuhzpt/. Diakses pada tanggal 30 Agustus 2021

[20] Novita, H., Zulfadly, Syarif, Irawati, C. (2018). Pengaruh Pemberian Berbagai Konsentrasi Ethepon Terhadap Pertumbuhan dan Hasil Tanaman Mentimun (Cucumis sativus L.) Varietas Lokal dan Antara. Universitas Islam Negeri Sultan Syarif Kasim Riau.

[21] Profil Desa Belancan. (2014). Karakteristik Tanah dan Iklim. Kecamatan Susut, Kabupaten Bangli Propinsi Bali

[22] Mukhlis. (2017). Unsur Hara Makro dan Mikro yang dibutuhkan oleh Tanaman. Dinas Pertanian Kabupaten Luwu Utara. https://dtphp.luwuutarakab.go.id/berita/3/unsur-hara-makro-dan-mikro-yang-dibutuhkan-olehtanaman.html?fb_comment_id=3189773321086078_3795980587132012. Diakses pada 23 Februari 2021

[23] Benediktus, D.SW., Eka, T.SP., Prapto, Y. (2016). Pengaruh Pemberian Magnesium, Boron dan Silikon terhadap Aktivitas Fisiologis, Kekuatan Struktural Jaringan Buah dan Hasil Pisang (Musa acuminata) "Raja Bulu" Effect of Magnesium, Boron and Silicon Addition to Physiological Activity, Fruit Tissue Structure Strength and Production of "Raja Bulu" Banana (Musa acuminata). Program Studi Agronomi, Fakultas Pertanian, Universitas Gadjah Mada 2) Departemen Budidaya Pertanian, Fakultas Pertanian, Universitas Gadjah Mada.

[24] Anna, M.A.S. (2012). Efektivitas Pupuk Organik Dan Etilen Pada Pertumbuhan Dan Produksi Stroberi (Fragaria Sp). Program Studi Agroteknologi Jurusan Budidaya Pertanian Fakultas Pertanian Universitas Hasanuddin Makassar.

[25] Sumarno. (2019). Good Agricultural Practice sebagai Perangkat Lunak Pertanian Modern https://balitkabi.litbang.pertanian.go.id/berita/good-agricultural-practices-sebagai-perangkat-lunakpertanian-modern/. Diakses pada tanggal 30 Agustus 2021 